\title{
Peran organisasi kemahasiswaan dalam menumbuhkan nilai-nilai karakter peduli sosial mahasiswa
}

\author{
Muhtar Galuh Ardian ${ }^{1}$, Aris Riswandi Sanusi ${ }^{1}$, Tridays Repelita ${ }^{1}$
}

${ }^{1}$ Program Studi Pendidikan Pancasila dan Kewarganegaraan, Universitas Buana Perjuangan, Karawang, Indonesia

\begin{tabular}{|c|c|}
\hline INFORMASI ARTIKEL & ABSTRAK \\
\hline $\begin{array}{l}\text { Sejarah Artikel: } \\
\text { Diterima: 02-11-2020 } \\
\text { Disetujui: } 30-06-2021\end{array}$ & $\begin{array}{l}\text { Penelitian ini bertujuan untuk mengetahui peran organisasi dalam menumbuhkan nilai- } \\
\text { nilai karakter peduli sosial. Penelitian ini menggunakan pendekatan kualitatif dengan } \\
\text { metode deskriptif. Subjek dalam penelitian ini ialah Dosen Pendamping Mahasiswa, } \\
\text { Pengurus Badan Eksekutif Mahasiswa Fakultas Keguruan dan Ilmu Pendidikan, dan }\end{array}$ \\
\hline $\begin{array}{l}\text { Kata kunci: } \\
\text { Organisasi, } \\
\text { Pembentukan karakter } \\
\text { peduli sosial, } \\
\text { Mahasiswa } \\
\text { Keywords: } \\
\text { Organization, } \\
\text { Formation of social caring } \\
\text { character, } \\
\text { Students }\end{array}$ & $\begin{array}{l}\text { Mahasiswa Fakultas Keguruan dan Ilmu Pendidikan, teknik pengumpulan data dalam } \\
\text { penelitian ini menggunakan wawancara, observasi, dan dokumentasi, sedangkan teknik } \\
\text { analisis data yang digunakan dalam penelitian ini adalah triangulasi. Hasil penelitian } \\
\text { menunjukkan bahwa pengurus badan eksekutif mahasiswa dalam menumbuhkan nilai- } \\
\text { nilai karakter peduli berhasil, tetapi keberhasilan tersebut hanya dapat dilakukan di } \\
\text { dalam internalisasi kepengurusan Badan Eksekutif Mahasiswa Fakultas Keguruan dan } \\
\text { Ilmu Pendidikan tidak secara menyeluruh terhadap mahasiswa fakultas keguruan dan } \\
\text { ilmu pendidikan. Rekomendasi penelitian ini, bagi universitas buana perjuangan selaku } \\
\text { penyelenggara pendidikan harus menekankan pembelajaran di dalam kelas bukan } \\
\text { hanya mengutamakan nilai intelektualitas saja tetapi aspek afektif dalam membentuk } \\
\text { karakter mahasiswa harus dilakukan secara optimal, bagi organisasi badan eksekutif } \\
\text { mahasiswa fakultas keguruan dan ilmu pendidikan harus mengintensifkan kegiatan } \\
\text { pembentukan karakter yang diselenggarakan dengan berpedoman dengan silabus dan } \\
\text { kurikulum organisasi, bagi mahasiswa fakultas keguruan dan ilmu pendidikan sudah } \\
\text { seharusnya memanfaatkan organisasi sebagai wadah pengembangan segala bentuk } \\
\text { potensi yang ada di dalam diri pribadinya. }\end{array}$ \\
\hline
\end{tabular}

\section{ABSTRACT}

This study aims to determine the role of the organization in fostering the values of the character of social care. This research uses a qualitative approach with descriptive methods. This study uses a qualitative approach with descriptive methods. The subjects in this study were Student Assistant Lecturers, Management of the Student Executive Board of the Teaching and Education Faculty, and Teaching and Education Faculty Students, the data collection techniques in this study used interviews, observation, and documentation, while the data analysis techniques used in this study is triangulation. The results show that the student executive board in cultivating the values of caring character is successful, but this success can only be done in the internalization of the management of the Student Executive Board of the Teaching and Education Faculty, not as a whole towards students of the teacher and education faculties. The recommendation of this research, for universities where the struggle as the provider of education must emphasize learning in the classroom not only prioritizing intellectual value but affective aspects in shaping student character must be done optimally, for the organization of the student executive body of the teacher training faculty and education science, it must intensify character building activities that are held guided by the syllabus and organizational curriculum, for students of the faculty of teacher training and education science, they should take advantage of the organization as a forum for developing all forms of potential that exist within themselves.

\section{Pendahuluan}

Setiap organisasi kemahasiswaan seharusnya menjadi wadah mahasiswa untuk mengekspresikan proses pengembangan diri, seperti halnya pengembangan karakter salah satunya bisa melalui organisas kemahasiswaan yang ada di dalam internal Universitas Buana Perjuangan Karawang, di dalam organisasi penanaman sampai dengan terbntuknya karakter mahasiswa akan cepat terbentuk dikarenakan organisasi adalah wadah yang tepat sebagai temapt pengembangan segala bentuk potensi yang ada di dalam diri mahasiswa. Seperti pada saat ini bahwa pendidikan 
karakter di dalam organisasi semakin menurun sehingga banyak sekali mahasiswa yang berkecimpung dalam dunia organisasi melupakan penanaman karakter dari setiap kegiatan-kegiatan organisasi yang mengakibatkan kemerosotan moral mahasiswa pada saat ini, sehingga pengembangan sumber daya manusia di negara Indonesia kurang maksimal.

Salah satu upaya peningkatan sumber daya manusia melaui bidang pendidikan mengacu pada pasal 3 undang-undang nomor 20 tahun 2003 tentang pendidikan nasional menjelaskan bahwa "fungsi pendidikan nasional mengembangkan kemampuan dan membentuk watak serta peradaban bangsa, bertujuan untuk berkembangnya potensi peserta didik agar menjadi manusia yang beriman dan bertaqwa kepada tuhan yang maha esa, berakhlak mulia, sehat, berilmu, cakap, kreatif, mandiri, dan menjadi warga negara yang demokratis serta bertanggungjawab" berdasarkan undang-undang tersebut bahwa tujuan pendidikan nasional bukan hanya mengutamakan aspek kogniitif saja tetapi seharusnya memperhatikan juga tentang aspek afektif dan psikomotorik.

Realitanya kondisi persoalan dalam dunia pendidikan menyebabkan tujuan nasional pendidikan nasional tidak tercapai dengan maksimal, dikarekanakan kurang di maksimalkannya pendidikan karakter di dalam perguruan tinggi berakibat pasifnya kegiatan-kegiatan sosial yang dilakukan oleh organisasi mahasiswa. Seharusnya kegiatan-kegiatan sosial secara terus menerus dilaksanakan didalam kegiatan organisasi mahasiswa, dengan adanya kegiatan-kegiatan sosial yang dilakukan oleh organisasi mahasiswa akan membuat mahasiswa meningkatkan kepedulian terhadap sosial, dilihat masa kini mahasiswa kepedulian sosialnya sudah sangat menurun dilihat pasifnya kegiatan organisasi mahasiswa yang hanya lebih fokus mengadakan kegiatan-kegiatan akademik saja di tengah-tengah keterpurukan nilai-nilai kepedulian sosia di dalam diri mahasiswa.

Majid \& Andayani (2013, hal. 54) menjelaskan bahwa rendahnya pendidikan karakter di Indonesia disebabkan oleh beberapa faktor. Pertama, sistem pendidikan yang kurang menekankan pembentukan karakter, tetapi lebih menekankan pada pengembangan intelektual. Kedua, kondisi lingkungan yang kurang mendukung pembangunan karakter yang baik." Karakter tidak begitu menjadi prioritas, padahal pengetahuan tanpa karakter (knowledge without character) Majid \& Andayani (2013) merupakan salah satu dari tujuh dosa yang mematikan. Perlu upaya berkesinambungan yang bisa dimulai menggunakan pendidikan karakter anak usia dini sampai mahasiswa di perguruan tinggi melaui pendidikan karakter. Selama ini pendidikan kita selalu menitikberatkan pada orientasi kognitif dengan mengesampingkan pendidikan karakter. Hal ini diperkuat oleh pendapat Supeni \& Saddhono (2013, hal. 156) yang menyatakan "Teachers tend to deliver material, and focuson cognitive aspect without developing the student's attitude and life values. Students as person do not get enough attention, therefore the knowledge that they master is not meaningful for themselves, life, and humanism." Hal senada juga disampaikan oleh Zuchdi (2015, hal. 2) yang menyatakan bahwa proses pendidikan dan pembelajaran yang berlangsung di dalam kelas hanya cenderung formalitas dan hanya mementingkan capaian akademik. Hal tersebut bertolak belakang dengan fungsi dan tujuan pendidikan nasional, yaitu pendidikan nasional berfungsi mengembangkan kemampuan dan membentuk watak serta peradaban bangsa yang bermartabat dalam rangka mencerdaskan kehidupan bangsa, bertujuan untuk berkembangnya potensi peserta didik agar menjadi manusia yang beriman dan bertakwa kepada Tuhan Yang Maha Esa, berakhlak mulia, sehat, berilmu, cakap, kreatif, mandiri, dan menjadi warga negara yang demokratis dan bertanggung jawab.

Pendidikan karakter bisa dilakukan dengan berbagai metode yaitu penanaman nilai, keteladanan nilai, fasilitasi nilai, dan keterampilan nilai (Kirschenbaum, 1995). Keteladanan menjadi aspek yang penting untuk membina karakter peserta didik. Hal tersebut disebabkan oleh keteladanan yang mementingkan perilaku secara nyata yang bisa dijadikan acuan oleh peserta didik. Widyaningsih, Zamroni \& Zuchdi (2014, hal. 189) menyatakan bahwa dalam strategi pembinaan karakter menjadi bagian dari pendekatan kompre-hensif yang merupakan sintesis dari dua metode tradisional yaitu metode penanaman nilai ketela-danan dan metode kontemporer melalui life skill. Menurut Lickona (Lickona, 2009) pendidikan karakter mempunyai tiga unsur pokok yaitu mengetahui kebaikan (knowing the good), mencintai kebaikan (desiring the good), dan melakukan kebaikan (doing the good). Di dalam pendidikan karakter tidak hanya tentang benar dan salah tetapi juga menanamkan suatu kebiasaan yang baik dengan harapan peserta didik paham dan mengimplementasikannya di dalam kehidupan sehari-hari. 
Berdasarkan penjelasan diatas peneliti bahwa penyeleggaraan pendidikan seharusnya bukan hanya fokus terhadap pengembangan inetelektual mahasiswa saja tetapi difokuskan pada pembentukan karakter agar mahasiswa mempunyai karakter untuk melakukan pembangunan bangsa lebih baik lagi. pembimbingan mahasiswa terfokus pada pembentukan jati diri dan kapasitas mahasiswa. Hal ini dapat dilihat pada sikap, perilaku, kepribadian, dan karakter yang baik. perguruan tinggi sebagai penyelenggara pendidikan mempunyai peran strategis dalam meningkatkan sumber daya manusia untuk lebih baik lagi sehingga masyakat menggantungkan harapan besar terhadap intansi-intansi penyelenggara pendidikan.

Maka dari pada itu pengembangan mahasiswa dapat dilakukan melalui organisasi kemahasiswaan yang diharapkan menghasilkan mahasiswa yang mempunyai wawasan luas, kreatvitas, gaya kepempinan, dan kepekaan sosial terhadap masyarakat. Kareakter peduli sosial ialah perilaku seseorang yang selalu bersikap ataupun bertindak peduli sesama atas dasar kebutuhan dan salah satu bentuk pertolongan, sebagai sebuah organisasi Badan Eksekutif Mahasiswa Fakultas Keguruan dan Ilmu Pendidikan (BEM FKIP) di harapkan menjadi suatu wadah dalam penanaman nilai-nilai karakter peduli sosial terhadap mahasiswa Fakultas Keguruan dan Ilmu Pendidikan (FKIP). Aktor-aktor dalam penanaman nilai-nilai karakter penduli sosial ialah pengurus Badan Eksekutif Mahasiswa Fakultas Keguruan dan Ilmu Pendidikan yang memberikan pengertian ataupun edukasi sikap kepedulian sosial terhadap mahasiswa FKIP mempunyai karakter peduli sosial. Berdasarkan latar belakang yang telah diuraikan diatas, maka perlu dilakukan penelitian tentang peran organisasi dalam menumbuhkan nilai-nilai karakter peduli sosial.

\section{Metode}

Metode penelitian yang digunakan dalam penelitian adalah kualitatif deskriptif. Menurut Sugiyono (2012, hal. 13) metode penelitian kualitatif adalah: "Metode penelitian kualitatif dapat diartikan sebagai metode penelitian yang berlandaskan pada filsafat pos positivisme, digunakan untuk meneliti pada kondisi objek yang alamiah, (sebagai lawannya adalah eksperimen) dimana peneliti sebagai instrumen kunci, teknik pengumpulan data dilakukan secara trigulasi (gabungan), analisis data bersifat induktif/kualitatif, dan hasil penelitian kualitatif lebih menekankan makna dari pada generalisasi." Menurut Sugiyono (2012, hal. 53) pendekatan deskriptif adalah: "penelitian deskriptif merupakan penelitian yang dilakukan untuk mengetahui keberadaan variabel mandiri, baik hanya pada satu variabel atau lebih tanpa membuat perbandingan atau menghubungkan dengan variabel lain (variabel mandiri adalah variabel yang berdiri sendiri, bukan independen selalu dipasangkan dengan dependen)." Metode penelitian yang digunakan dalam penelitian ini adalah deskriptif kualitatif karena penelitian berjuang untuk mendeskripsikan atau menggambarkan tentang peran organisasi dalam menumbuhkan nilai-nilai karakter peduli sosial.

\section{Hasil dan Pembahasan}

Organisasasi pada hakikatnya ialah tempat untuk mengembangkan segala bentuk potensi yang dimiliki suatu individu dalam setiap proses yang terjadi untuk mencapai suatu tujuan tertentu. Organisasi mempunyai suatu aturan untuk yang sangat fundamentalis untuk mengatur jalannya roda organisasi dalam setiap gerakanya agar sesuai dengan rule yang ditentukan agar tercapainya suatu tujuan organisasi yang digagas atas dasar daripada suatu persamaan rasa dari setiap individu maupun kelompok.

Standarisasi keberhasilan suatu organisasi dapat dilihat dari pada suatu kesadaran dari individu mengisi komposisi struktural yang mempunyai suatu tujuan bersama dan dapat berkolaborasi dari setiap gagasan untuk dituangkan dalam ketercapaian suatu tujuan organisasi itu sendiri yang berlandaskan pada gotong dan bernafaskan pada titik kekeluargaan serta profesionalisme dalam setiap gerakan organisastoris ketika menjalankan organisasi itu sendiri, berbicara pada suatu tatanan gerakan organisasi, seharusnya organisasi mempunyai suatu aturan yang mengatur jalanya organisasi sebagai landasan yang sangat fundamentalis untuk mencapai suatu tujuan yang hendak dicapai oleh setiap pengurus organisasi. 
Taraf keberhasilan organisasi bisa dilihat dalam setiap langkahnya yang mempunyai suatu landasan aturan untuk mengikat sekelompok orang, dalam hal ini sebagai wadah pengembangan segala bentuk potensi yang dimiliki oleh setiap organisasi maka harus adanya pedoman-pedmoan yang dimiliki setiap organisasi yang membahas langkah daripada suatu organisasi untuk mencapai suatu tujuannya, konseptual untuk membuat suatu pola ideologisasi dan kaderisasi guna memberikan suatu penyadaran dalam bentuk gagasan dalam membentuk, mengasah, menanamkan nilai-nilai karakter peduli sosial didalam kalangan mahasiswa

Mahasiswa pada umumnya memiliki suatu peribawa sifat dan wataknya masing-masing yang sudah terbentuk sebelum ia memasuki perguruan tinggi dan menyandang gelar mahasiswa. Watak dan perilaku yang dimiliki oleh setiap individu kemudian hal tersebut menjadi ciri khas dari seseorang/ individu itu sendiri yang dinamakan dengan karakter. Pada intinya karakter adalah suatu sifat, perilaku, watak, kejiwaan seseorang, akhlak yang ada didalam diri individu yang menjadi suatu ciri khas dari pada setiap individu.

Karakter mahasiswa tentunya harus dilandasi dengan nilai-nilai yang tidak bertentangan dengan norma yang hidup di kalangan masyarakat, karakter yang dilandasi dengan nilai-nilai norma yang hidup di masayarakat tentunya tidak akan menimbulkan suatu penyimpangan sosial dari setiap perilaku individunya. Pembentukan karakter dari setiap individu dapat dipengaruhi oleh lingkungan yang mempengaruhi suatu pemikiran dan akan diucapkan dalam suatu bentuk komunikasi oleh setiap individu dengan individu lainnya serta akan berbuah dalam bentuk tindakan yang dilakukan oleh setiap individu itu sendiri dalam setiap perilakunya, selanjutnya tindakan dan perilaku yang dilakukan secara terus-menerus oleh setiap individu akan menjadi suatu kebiasaan dalam menjalani kehidupan sehari-harinya dan kebiasaan tersebut akan karakter individu itu sendiri.

Organisasi sebagai wadah pengembangan segala bentuk potensi yang ada di dalam diri mahasiswa harus mampu mengarahkan, membentuk, mengasah, dan menanamkan nilai-nilai karakter salah satunya nilai karakter peduli sosial yang harus ditanamkan dalam organisasi kemahasiswaan. Proses pembentukan karakter peduli sosial itu sendiri bisa dilakukan atau diupayakan oleh organisasi melalui setiap kegiatan organisasi yang dimana harus menyisipkan nilainilai karakter peduli sosial untuk menuntut dan menumbuhkan karakter kepedulian sosial dikalangan mahasiswa itu sendiri.

Proses pembentukan karakter peduli sosial yang dilakukan oleh organisasi bukan hanya melalui kegiatan yang diselenggarakan oleh organisasi saja tetapi aspek lainpun harus diperhatikan seperti silabus, kurikulum, aturan organisasi sebagai acuan dasar untuk penentuan langkah yang teratur sesuai dengan rule dan konseptual yang digagas dan dituangkan untuk menciptakan suatu lingkungan sekeliling yang selalu memperlihatkan kepedulian sosial, untuk mencapai hal tersebut maka setiap pengurus organisasi harus mengimplementasikan terlebih dahulu tentang nilai-nilai karakter peduli sosial yang tertuang didalamnya.

Secara umum pendidikan didefinisikan sebagai sebuah usaha secara sadar dan terencana agar mewujudkan suasana belajar dengan proses pembelajaran supaya peserta didik secara aktif mengembangkan potensi dirinya untuk memiliki kekuatan spiritual keagamaan, pengendalian diri, kepribadian, kecerdasan, akhlak mulia serta keterampilan yang diperlukan dirinya dan masyarakat. Di dalam pendidikan terdapat suatu proses pembelajaran yang dilakukan oleh manusia secara terus menerus sehingga manusia bisa menjadi pribadi yang amil (sempurna) secara lahir dan batin. Apabila dalam proses pendidikan menghasilkan output yang mempunyai pribadi yang lemah, suka KKN, tidak bertanggung jawab, tidak bermoral, dan tidak mandiri, maka berarti program pendidikan itu gagal. Kegagalan tersebut mungkin disebabkan karena adanya kesalahan dalam filosofi maupun manajemen pendidikan sehingga tidak sesuai dengan cita-cita pendidikan itu sendiri (Kadir, 2018, hal. 25-26).

Tujuan pendidikan pada hakikatnya membentuk kepribadian, kemandirian, keterampil-an sosial, dan karakter. Perguruan Tinggi merupa-kan sebuah lembaga akademik yang mempunyai tugas utama untuk menyelenggarakan pendidikan serta mengembangkan ilmu pengetahuan dan teknologi serta seni. Apabila hakikat dari pendi-dikan tersebut bisa tercapai maka diharapkan dapat membentuk karakter calon generasi penerus bangsa yang kokoh sehingga bisa untuk meminimalisir bahkan menghilangkan korupsi di instansi-instansi pemerintah maupun swasta. Wren (2008) yang menekankan tentang perlunya pendidikan moral untuk peserta didik melalui sisi luar dan dalam. 
Pendidikan moral digunakan untuk melakukan kontrol sosial seseorang, sehingga diharapkan dapat mengubah perilaku. Dengan adanya perubahan perilaku ke arah yang lebih baik maka akan membuat karakter dari peserta didik menjadi lebih kuat dan sebagai bekal fondasi kejujuran di masa yang akan datang. Pendidikan di Indonesia yang sebagian besar berorientasi ke arah kognitif saja juga belum membuahkan hasil yang memuaskan yang hal ini bisa menambah catatan hitam pendidikan di Indonesia. menurut survei yang dilakukan oleh Organization for Economic Cooperation and Development (OECD) terhadap hasil tes di 76 negara, Indonesia berada pada posisi ke-69. Peringkat ini didasarkan pada mata pelajaran Matematika dan Science pada saat anak berusia 15 tahun (Coughlan, 2015).

Manusia baik sebagai individu maupun sebagai suatu kelompok masyarakat hidup dalam ruang sosial dan menciptakan kebudayaan, membina, mengembangkan, dan melestarikannya, serta hidup dalam warna atau corak kebudayaannya sendiri. Semenjak manusia diciptakan maka semenjak itu pula pendidikan telah dilaksanakan, artinya usia pendidikan sama dengan usia manusia. Dalam proses pendidikan dan proses pewarisannya juga telah mengedepankan etika atau moral yang berlaku dan berlangsung di masanya, dimana akan selalu melakukan perbuatan baik dengan mengadaptasi lingkungan dan budaya yang ada di lingkungannya. Untuk itu diperlukan wawasan, pengetahuan, dan keterampilan yang diperlukan untuk survive bagi generasi berikutnya. Dalam konteks abad 21, pendidikan harus mampu mengembangkan manusia yang memiliki keterampilan untuk sukses di dunia saat ini, seperti pemikiran kritis, memecahkan masalah, berkomunikasi, dan berkolaborasi (Partnership for 21st Century Learning, 2015). Namun demikian, tujuan pendidikan tidak hanya sukses di dunia, namun juga harus mampu menumbuhkan kecerdasan hati yang menuntun manusia kembali pada penciptanya dengan keimanan dan ketakwaan sebagaimana tujuan pendidikan nasional di Indonesia.

Bergulirnya waktu pendidikan telah mengalami evolusi dari yang paling sederhana menjadi yang lebih kompleks, sehingga dalam prosesnya pun telah mengalami perkembangan yang sangat pesat di berbagai aspek kehidupan. Etika dalam proses mencapai tujuan pendidikan tidak dapat dipisahkan, karena hal ini terkait hasil akhirnya dimana proses pendidikan yang berlangsung secara etis dan terus-menerus dalam kehidupan seseorang melalui pengajaran dan penekanan terhadap etika itu sendiri sehingga kemampuan, bakat, kecakapan dan minatnya dapat dikembangkan seimbang dengan etika yang baik dan benar dalam kehidupannya. Proses ini dapat dilihat dari awal proses pendidikan di dalam keluarga, orang tua memberikan bekal pengetahuan dan keterampilan dilingkunganya dengan cara suri teladan, yaitu memberikan contoh tentang sopan santun sesuai etika yang baik juga pendidikan agama kepada anak-anaknya sehingga mereka tahu dan terampil hidup di tengah masyarakat dengan etika dan moral hidup yang baik. Demikian juga anak-anak akan menjadi dewasa dan akan mewariskan ke generasi berikutnya dari yang pernah dipelajari dan dialaminya dari kecil dan seterusnya. Pendidikan bermaksud membantu peserta didik untuk menumbuh kembangkan potensi-potensi kemanusiaannya. Potensi kemanusiaan merupakan benih kemungkinan untuk menjadi manusia. Pendidikan itu berlangsung dengan baik dan berhasil, jika seorang pendidik memahami dan menerapkan konsep keteladanan yang baik berdasarkan etika dan moral yang baik.

Manusia memiliki cara hidup yang penuh dengan nilai-nilai baik dan luhur dalam kehidupannya, sedangkan tujuan pendidikan memuat gambaran tentang nilai-nilai yang baik, luhur, pantas, benar, dan indah untuk kehidupan. Pendidikan memiliki dua fungsi yaitu memberikan arah kepada segenap kegiatan pendidikan dan merupakan sesuatu yang ingin dicapai oleh segenap kegiatan pendidikan. Untuk dapat mencapai tujuan pendidikan yang lebih baik perlu adanya kepastian dan jaminan hukum terutama dalam pendidikan formal, sehingga perlu dibentuk suatu peraturan atau hukum yang melindungi peserta didik, proses pendidikan dalam mencapai tujuan. Dalam proses pengembangan potensi manusia, maka seyogianya dirumuskan atau direncanakan suatu pendidikan yang mampu memberikan wadah dalam mengupayakan pengembangan potensi setiap individu yang beraneka ragam.

\section{Simpulan}

Upaya organisasi dalam menumbuhkan nilai-nilai karakter peduli sosial, merujuk pada polarisasi perilaku pengurus organisasi yang harus menanamkan nilai-nilai karakter peduli sosial di kehidupan sehari-harinya yang nantinya pengurus organisasi akan menjadi suatu panutan bagi mahasiswa lain yang tidak terlibat secara langsung, aspek kedua, implementasi nilai-nilai karakter 
peduli sosial melalui kegiatan yang diselenggarakan oleh organisasi dengan objek keterlibatan mahasiswa Fakultas Keguruan dan Ilmu Pendidikan dalam pengemasan secara kajian maupun pelatihan. Aspek yang ketiga ialah pada dasarnya organisasi harus mempunyai suatu landasan yang fundamental sebagai konsep untuk mengatur jalannya roda organisasi dalam pembentukan, pengasahan, pelatihan, maupun penanaman nilai-nilai karakter peduli sosial.

\section{Referensi}

Coughlan, S. (2015). Asia peringkat tertinggi sekolah global, Indonesia nomor 69 - BBC News Indonesia. BBC.

Kadir, Y. (2018). Kebijakan pendidikan antikorupsi di perguruan tinggi. Gorontalo Law Review, 1(1), 25-38.

Kirschenbaum, H. (1995). 100 ways to enhance values and morality in schools and youth settings. Allyn \& Bacon.

Lickona, T. (2009). Educating for character: How our schools can teach respect and responsibility. Bantam Books.

Majid, A., \& Andayani, D. (2013). Pendidikan karakter perspektif Islam. PT. Remaja Rosdakarya.

Partnership for 21st Century Learning. (2015). P21 partnership for 21st century learning. In Partnership for 21st Century Learning.

Sugiyono. (2012). Metode penelitian kuantitatif kualitatif dan R\&D. Alfabeta.

Supeni, S., \& Saddhono, K. (2013). Cognitive behavior has replaced the Javanese traditional values in global era. Asian Journal of Management Sciences and Education, 2(2), 156-162.

Widyaningsih, T. S., Zamroni, \& Zuchdi, D. (2014). Internalisasi dan aktualisasi nilai-nilai karakter pada siswa SMP dalam perspektif fenomenologis. Jurnal Pembangunan Pendidikan: Fondasi dan Aplikasi, 2(2), 181-195.

Wren, T. (2008). Philoshopical morings. In L. P. Nucci \& D. Narvaez (Ed.), Handbook of moral and character education (hal. 11-29). Francis Group.

Zuchdi, D. (Ed.). (2015). Pendidikan karakter: Konsep dasar dan implementasi di perguruan tinggi. UNY Press. 